\title{
Reproductive biology in monoecious and gynoecious cucumber cultivars as a result of IBA application
}

\author{
Valdir Diola; Afonso I Orth; Miguel P Guerra
}

UFSC - CCA, Dep ${ }^{\text {to. }}$ Fitotecnia, Progr. pós-graduação em Recursos Genéticos Vegetais, C. Postal 476, 88040-900 Florianópolis-SC; valdirdiola@vicosa.ufv.br; aorth@mbox1.ufsc.br; mpguerra@ufsc.br

\begin{abstract}
The understanding of both the reproductive biology and the regulation of the sexual expression of cucumber flowers (Cucumis sativus) makes crop management easier and can improve fruit yield and quality. The objective of this study was to evaluate the physiological answer of cucumber floral verticils to the application of IBA. The experiment was carried out in a greenhouse, in completely randomized blocks, with four replications of 4-plant plots, and treatments applied to a 5 x 2 factorial $(0,50,100,200$, and 500 $\mu \mathrm{mol}$ of IBA, and two cultivars: Wisconsin MR28, gynoecious, and Caipira, monoecious). Cultivar Wisconsin MR28 produced in average 7,636 pollen grains (PG) per flower, with a positive linear response to the increase in IBA concentration. Instead, in cultivar Caipira (5,160 PG) all IBA concentrations reduced PG production. Cultivars did not differ from each other in relation to PG viability (average in vitro germination of 75.4 and $79.9 \%$ to cultivars Wisconsin MR28 and Caipira, respectively) and in both PG viability increased linearly with the increase in AIB concentration. Cultivars Wisconsin MR28 and Caipira presented in average 71.6 and 70.6 seeds per fruit respectively, and responded with an increase in seed number and improvement in fruit general aspect to the rise in IBA concentration. The ratio male:female flowers was significantly different between cultivars (4.2:1 and 3.5:1, respectively to cultivars Wisconsin MR28 and Caipira) and responded in a distinct way to IBA concentrations. While in cultivar Caipira, IBA concentrations near to $100 \mu \mathrm{mol}$ increased the number of male flowers; in cultivar Wisconsin MR28 the same IBA concentration reduced it. The two cultivars had a similar number of female flowers. However, whereas it remained relatively stable in cultivar Caipira in spite of the increase in IBA concentration, there was an increase in the number of female flowers in cultivar Wisconsin MR28, as a result of the rise in IBA concentration.
\end{abstract}

Keywords: Cucumis sativus, fecundation, flowering, viability pollen, plant hormones.

\section{RESUMO}

Biologia reprodutiva de cultivares monóicas e ginóicas de pepino em função do uso de AIB

A compreensão da biologia reprodutiva e da regulação da expressão sexual das flores do pepineiro (Cucumis sativus) pode facilitar o manejo do cultivo e melhorar a produção e a qualidade dos frutos. O objetivo do presente estudo foi avaliar a resposta fisiológica dos verticilos florais à aplicação de AIB em pepino. O experimento foi conduzido em casa-de-vegetação, em blocos casualizados, com os tratamentos dispostos em fatorial 5 x 2 (AIB nas concentrações de 0, 50, 100, 200 e 500 ìmol, para as cultivares Wisconsin MR28, ginóica, e Caipira, monóica). Foram utilizadas quatro repetições, com quatro plantas por parcela. A cultivar Wisconsin MR28 produziu em média 7.636 grãos de pólen (GP) por flor, com resposta linear positiva ao aumento nas concentrações de AIB. Já na cultivar Caipira (5.160 GP), todas as concentrações de AIB interferiram negativamente na produção de GP. As cultivares não diferiram entre si e em ambas houve efeito linear positivo da concentração de AIB sobre a viabilidade dos GP (germinação média in vitro de 75,4 e 79,9\% para as cultivares Wisconsin MR28 e Caipira, respectivamente). As cultivares Wisconsin MR28 e Caipira apresentaram em média 71,6 e 70,6 sementes por fruto respectivamente, respondendo com aumento no número de sementes e melhoria do aspecto do fruto ao incremento da concentração de AIB. A relação de flores masculinas:femininas diferiu significativamente entre cultivares (4,2:1 e 3,5:1 respectivamente para as cultivares Wisconsin MR28 e Caipira) e foi afetada de forma distinta nas duas cultivares pelas concentrações de AIB: concentrações próximas de $100 \mu \mathrm{mol}$ aumentaram o número de flores masculinas na cultivar Caipira e reduziram na cultivar Wisconsin MR28. A quantidade de flores femininas foi semelhante entre as cultivares e relativamente constante na cultivar Caipira nas diferentes concentrações de AIB. Já na cultivar Wisconsin MR 28, houve aumento do número de flores femininas em função da elevação da concentração de AIB.

Palavras-chave: Cucumis sativus, fecundação, floração, viabilidade de pólen, hormônio vegetal.

(Recebido para publicação em 1 de outubro de 2006; aceito em 6 de fevereiro de 2008)

$I^{\prime}$ n the Brazilian vegetable growing sector, the economic value of cucumber (Cucumis sativus) is quite relevant for the continuation and development of the farms devoted to its exploitation. The average yield is approximately $10 \mathrm{t} \mathrm{ha}^{-1}$ for the pickle type, and $21 \mathrm{t} \mathrm{ha}^{-1}$ for the fresh type (IBGE, 2005). Yield potential is not fully achieved due to several reasons, among them, inadequate plant nutritional status and adverse climatic, biotic, and physiological aspects (Silva et al., 1992). Concerning endogenous reasons, cultivar influence on yield stands out, moreover when it involves the plant physiological response to hormone concentration (Stankovic \& Prodanovic, 2002).

A plant process highly affected by hormones is the onset of the reproductive cycle. Cucumbers possess a unisexual floral biology, with a monoecious behavior (Silva et al., 1992). The vertical growth habit promotes apical dominance, which is also stimulated by the high production and concentration of auxins in stem meristems. Such plant architecture aids the basipetal hormone transportation (Brenda et al., 1979). By means of both 
external and internal stimuli, the auxin synthesis is unchained, starting up the biochemical signaling that results in the activation of homeotic genes in the reproductive buds (Kater et al., 1998). As consequence, an early regulation of the floral verticils development takes place. In cucumber, plant manipulation through the induction of sexual expression differs among cultivars (Nienhuis et al., 1979), with the auxin signaling directly inducing three physiological functions: suppression of lateral bud development, differentiation, and definition of lateral meristems into more complex floral tissues (Stankovic \& Prodanovic, 2002).

The hormonal concentration, especially of auxins, in species with monoecious flowers, such as cucumbers, will define also the flower sex (Mendonza, 1982). High auxin concentration tends to promote ethylene synthesis in doses that favors the development of female flowers (Takahashi \& Jaffe, 2003). Thus, an adequate manipulation of auxins to stimulate meristematic processes would increase the female/male flowers rate (Dan et al., 2003). In spite of needing androgynous flowers, the female:male flower ratio is extremely relevant, since only gynosporangia turn into economic products.

Nitrogen nutrition in appropriate doses contributes to the auxin biosynthesis, while the plant structure interferes with its translocation and transportation, playing a role on the definition of flower sex (Nienhuis \& Lower, 1979). The early fruit development is also influenced by the biochemical signaling derived from hormone action and control, mainly of those hormones synthesized in the apical meristem (Godoy \& Cardoso, 2004). Other factors, such as pollen quality and pollination and fecundation efficiency may also impact fruit development and yield (Silva et al., 2000).

The hypothesis in the current study is that sex expression in cucumber flowers is mediated by the signaling from different auxin concentrations, as demonstrated by Kater et al. (2001). Consequently, it is expected that appropriate concentrations of this phytohormone in flower meristems would induce physiological alterations in floral tissues and verticils, which will lead to the growth of either androsporangia or megasporangia. Thus, the objective was to evaluate the physiological effect over such reproductive structures of their induction by exogenous application of 3-indolbutiric acid (IBA) in monoecious and gynoecious cucumber cultivars.

\section{MATERIAL AND METHODS}

The experiment was carried out from October to November, 2004, at the Federal University of Santa Catarina, in Florianópolis, Brazil. Plants grew in 8L pots, in protected cultivation, driven by a net system, according to Silva et al. (1992). Formulated fertilizer NPK (05-10-10) was balanced by adding $\mathrm{H}_{3} \mathrm{BO}_{3}^{-}(17)+\mathrm{MgSO}_{4} 7 \mathrm{H}_{2} \mathrm{O}(16-24)+$ $\mathrm{Ca}\left(\mathrm{NO}_{3}\right)_{2}-4 \mathrm{H}_{2} \mathrm{O}$ (15-14), following the recommendation of the Official Network of Soil Analysis Laboratories, adjusting the fertilization levels to 60100-80-60-20-20-5 ppm of respectively N-P-K-Ca-Mg-S-B. The experimental design was of completely randomized blocks, with four replications and fourplant plots. Treatments were disposed in a 5 x 2 factorial, corresponding to five IBA concentrations (0, 50, 100; 200 e 500 ìmol) and two cultivars (Wisconsin MR28 - gynoecious, and Caipira monoecious).

The experiment started 30 days after sowing, with the removal of all visible floral buds in all plants. Following, 2.0 $\mathrm{mL}$ of the IBA solutions were directly applied over the floral meristems, every other day, for 28 days, using a Pauster pipette. The three youngest leaves received from four to six drops of the same solutions, in the adaxial surface. The surfactant Herbitensil ${ }^{\circledR}$ (aqueous solution with $400 \mathrm{~g} \mathrm{~L}^{-1}$ of nonylphenol ethoxylate and $150 \mathrm{~g} \mathrm{~L}^{-1}$ of isopropilic alcohol) was added to the auxin solutions in the concentration of $1.0 \mathrm{~mL}$ $\mathrm{L}^{-1}$. Ten days after AIB application, fresh pollen was collected and used for the pollination in the different treatments. Female flowers selected for the controlled pollination were protected in the bud stage, for four days, using waterproof paper bags. Fertilization efficiency was estimated in four fruits per treatment eight days after pollination by counting fecundated and nonfecundated ovules in two perpendicular and longitudinal fruit sections (Figures $1 \mathrm{a}$ and $\mathrm{b}$ ).

The number of pollen grains was assessed in samples of four flowers in the ball stage per treatment. All anthers in each flower were mashed in microtubes, with 500 ì of lactic acid 85\% (Gomes et al. 2003). Two 3.0 ìLaliquot samples of this suspension were used for evaluation. Pollen grain counting was carried out in stereomicroscope $(10 \mathrm{x})$, using the scanning field method. Three flower in the ball stage and three anthers per flower were used to evaluate the potential of pollen grains in vivo. Anthers were mashed over glass slides, colored with acetic carmine $2 \%$, and assessed five minutes later, in a stereomicroscope (10x). The cytoplasm of viable pollen grains reacted with the acetic carmine becoming reddish, while the cytoplasm of unviable pollen grains remained translucid. Pollen grains in two vision fields per slide were counted to calculate the percentage of pollen viability. Four flowers per treatment were used for estimating pollen grain viability in vitro. Pollen grains were placed in Petri dishes filled with agarose gel 2\% + sucrose $20 \%$ + boric acid 0,03\%, and incubated at $26^{\circ} \mathrm{C}$, in the dark, in a BOD. Assessment was carried out 24 hours after induction, by counting the germinated pollen grains. Germination was characterized by the emission of the pollinic tube in a 2/1 length $\mathrm{x}$ diameter ratio (Bueno \& Cavalcanti, 2003). The male/female flower ratio was assessed by counting all flowers developed during the experiment.

Data were submitted to multiple regression analysis, while means were compared by the F test, $\mathrm{P}<0.05$, using the Software Statistica.

\section{RESULTS AND DISCUSSION}

The estimated averages for number of pollen grains in cultivars Wisconsin MR28 and Caipira, respectively 7,636 and 5,160, differed significantly from 


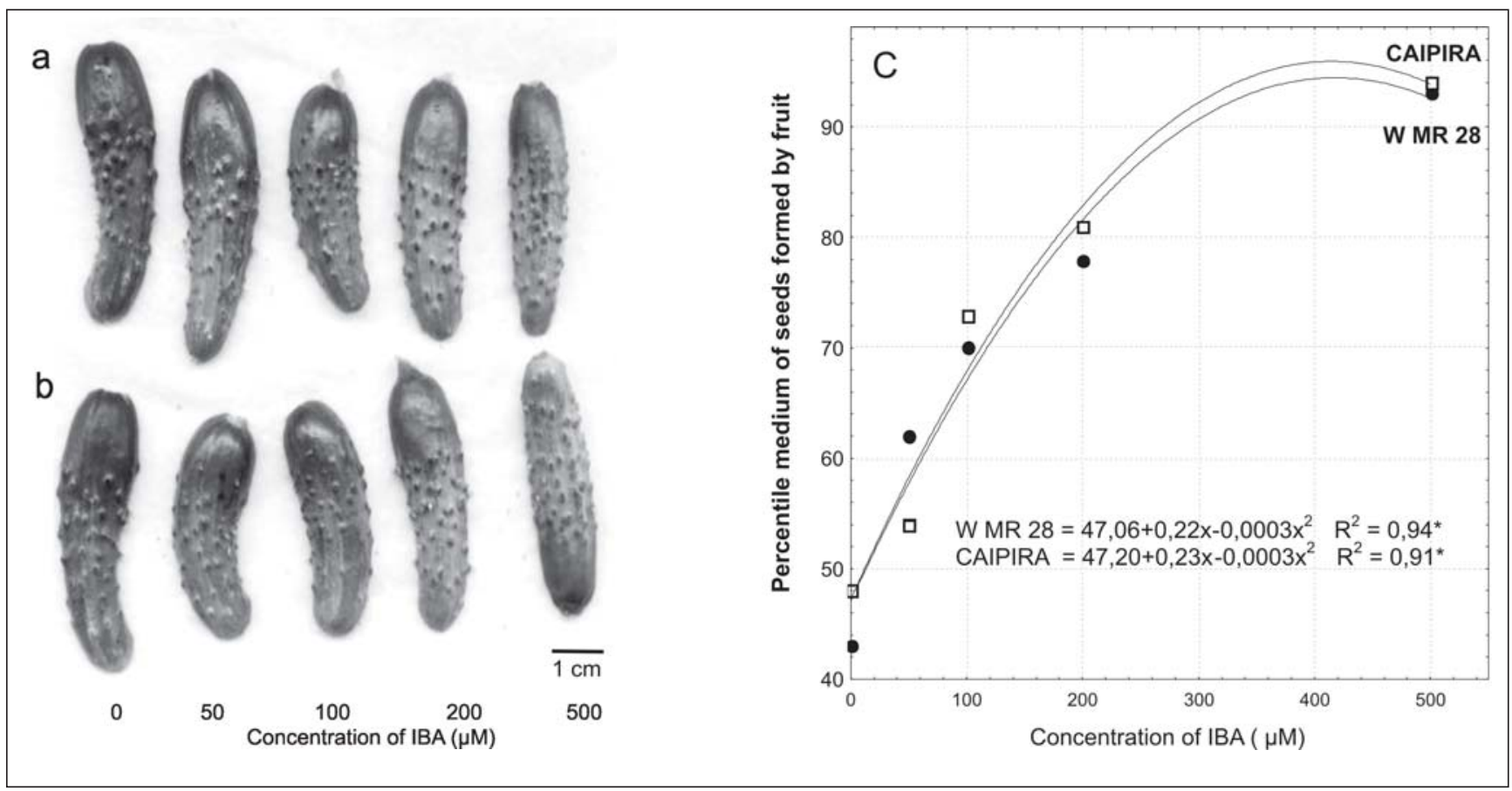

Figure 1. Aspect of cucumber fruits of cultivars (a) Wisconsin MR28, pickle type, and (b) Caipira, fresh type, and (c) percent increment on seeds as affected by the increase in IBA concentration (aspecto dos frutos de pepino das cultivares (a) Wisconsin MR28, tipo conserva, e (b) Caipira, tipo salada, e (c) acréscimo percentual de sementes formadas em função do aumento da concentração de AIB). Florianópolis, UFSC, 2004.

*Significativo pelo teste de $F$; $\mathrm{p}<0.05$ (Significant by the $F$ test, $\mathrm{p}<0.05$ ).

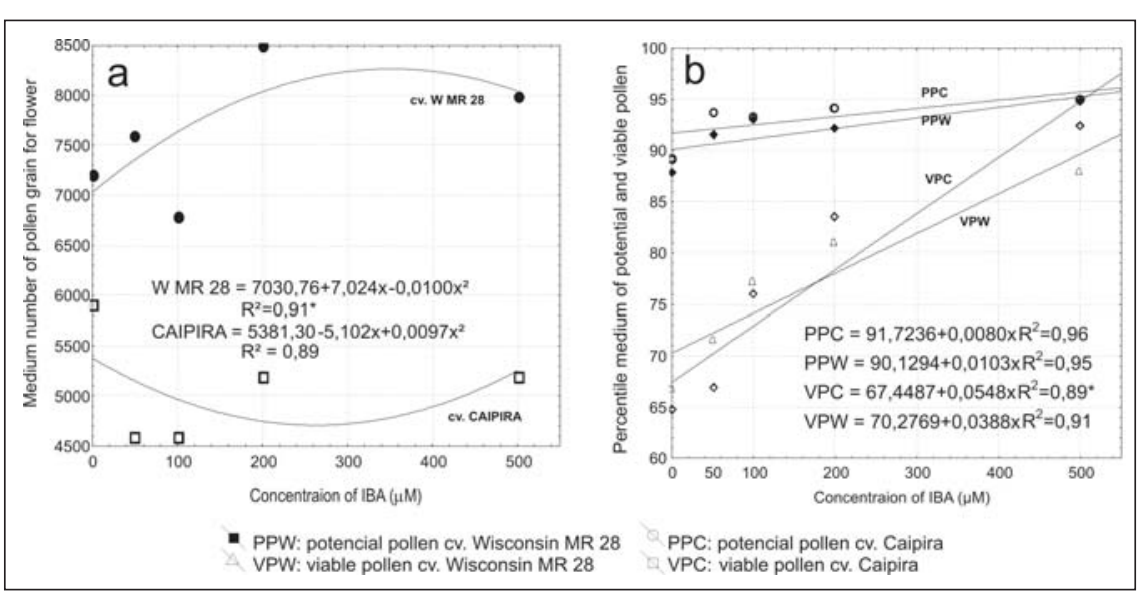

Figure 2. (a) Average number of pollen grains per flower and (b) average percent of pollen potential and viability as affected by the increase in IBA concentration, in two cucumber cultivars ((a) número médio de grãos de pólen por flor e (b) percentual médio de pólen potencial e pólen viável em função do aumento da concentração de AIB, em duas cultivares de pepino). Florianópolis, UFSC, 2004.

*Significativo pelo teste $F, \mathrm{p}<0,05$ (significant by the $F$ test, $\mathrm{p}<0.05$ ).

each other and were altered diversely by treatments (Figure 2a). Cultivar Wisconsin MR28 responded to the increase in IBA concentration by raising the average number of pollen grains, while in cultivar Caipira all IBA concentrations hindered pollen grain production (Figure 2a).
It was observed that 91.7 and $92.9 \%$ of the pollen grains of respectively cultivars Wisconsin MR28 and Caipira reacted to the acetic carmine and, therefore, are potentially viable. In both cultivars, IBA concentrations altered significantly pollen viability. Within the studied limits, there was a positive linear effect of the interaction between IBA doses and pollen potential capacity (Figure 2b). The estimated averages for in vitro pollen viability in cultivars Wisconsin MR28 and Caipira, respectively 75.4 e $79.9 \%$, were statistically similar (Figure 2b). Regarding IBA application, there was a positive linear effect of IBA concentrations over in vitro pollen viability, in both cultivars. Hence, the highest IBA concentrations resulted in the highest estimates of in vitro pollen viability (Figure 2b).

The number of seeds per fruit did not differ between cultivars. Fruits of cultivar Wisconsin MR28 had in average 71.6 seeds, while fruits of cultivar Caipira had 70.6. The highest concentrations of IBA induced a significant increase in the number of seeds per fruit (figure 1c). As consequence, fruit commercial aspect improved (Figure 1a and 1b).

Male:female flower ratios for cultivars Wisconsin MR28 and Caipira were $4.2: 1$ and 3.5:1, respectively, a significant difference. It was observed also that IBA concentrations altered 
significant and differently this ratio (Figure 3). Concentrations around 100 $\mu$ mol induced a peak of male flowers in cultivar Caipira and the strongest reduction in them in cultivar Wisconsin MR28 (Figure 3). There were not significant differences in number of female flowers between cultivars, although IBA concentrations altered it in a different way in each cultivar, likewise what was observed for the male:female flower ratio. While in cultivar Caipira, the number of female flowers remained constant in spite of changes in IBA concentration, in cultivar Wisconsin MR28 the amount of female flowers increased along with IBA concentrations (Figure 3).

Growth regulators in different concentrations alter the expression of several genes (Friedlander et al., 1977). Homeotic genes of the MADbox type may differ within a species, since they are regulated not only by genetics, but also by environmental stimuli (Yin \& Quinn, 1995). Such stimuli induce the biosynthesis of the phytohormones that regulate the expression of genes responsible for the cellular further development (Kater et al., 2001), like the definition of floral sex in monoecious plants. When environmental variations happen, auxin is one of the first growth regulators whose biosynthesis is altered (Taiz \& Zeiger, 2002). In this experiment, when it comes to the average number of pollen grains, cultivars responded differently to the variation in auxin concentration. This indicates that the growth regulator may act over the androspore formation inside the androsporangium, like what was observed also by Stankovic \& Prodanovic (2002). Our assays to check pollen potential and viability presented an interesting behavior. The application of IBA at $500 \mu \mathrm{mol}$ substantially raised pollen germination, in fact up to close to full potential. It demonstrates that this growth regulator may improve the biological conditions to the androspore and aid the development of the pollinic tube. Similar effect was described by Nijs \& Visser (1999), when investigating the compounds that induced flower masculinity in gynoecious cucumbers. In the current

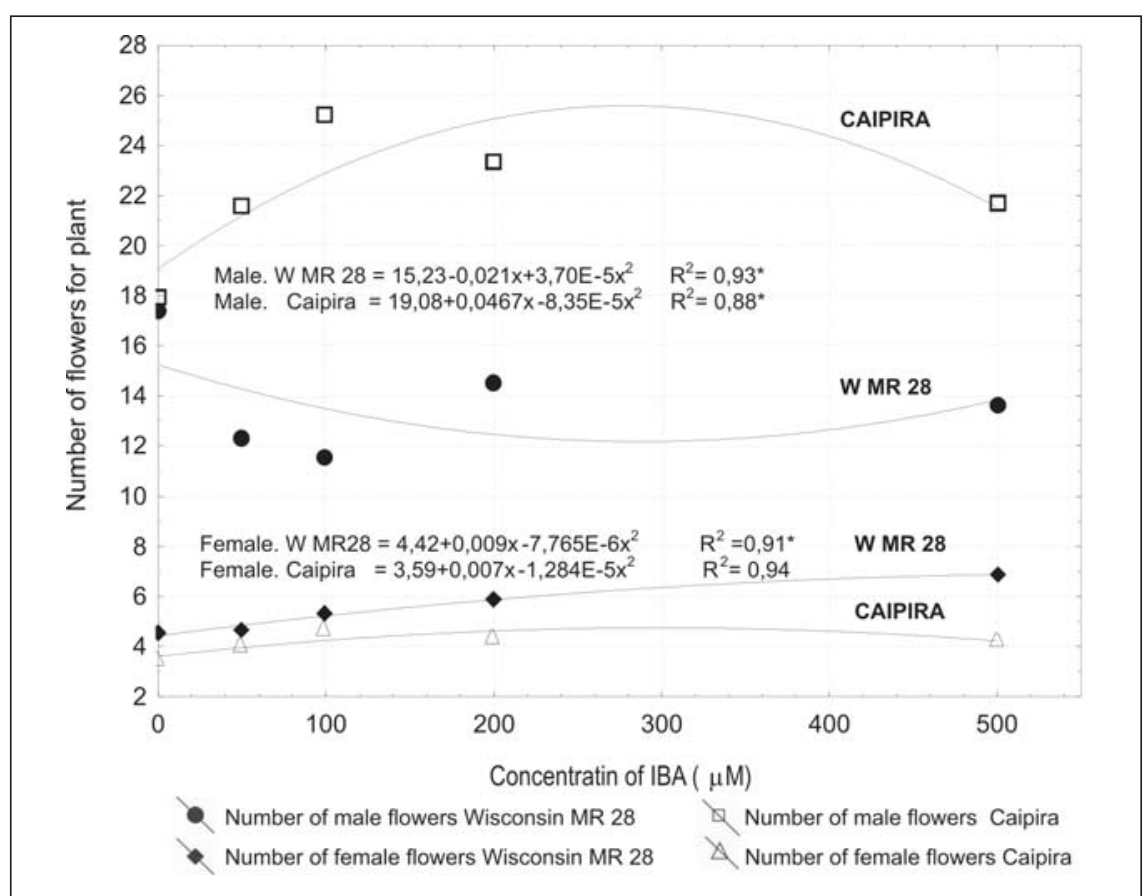

Figure 3. Male:female flower ratio, as affected by the increase in IBA concentration in two cucumber cultivars (relação número de flores masculinas:femininas, em função do aumento da concentração de AIB, em duas cultivares de pepino). Florianópolis, UFSC, 2004.

*Significativo pelo teste $F, \mathrm{p}<0.05$ (significant by the $F$ test, $\mathrm{p}<0.05$ ).

study, the analysis of fruits originated from fertilization with pollen from the same treatment and cultivar showed that fecundity was higher in the treatments with the highest IBA concentrations.

Takahashi \& Jaffe (2003) carried out research on the effects of ethylene over the cellular development of cucumber flowers, and concluded that ethylene was more efficient on female flowers. High auxin concentration unchains the ethylene biosynthesis (Taiz \& Zeiger, 2002) and, in such environment, ethylene may exert its influence on the behavior and differentiation of reproductive buds. Ethylene regulates the speed of cellular growth and the biosynthesis of other hormones, producing defined organs (Kater et al., 1998). This hypothesis could be observed, for there were not highly significant variations in the flower ratio, but on improving the development of fruits with more seeds and on increasing pollen viability.

IBA application resulted in similar stimuli and reactions in both cucumber cultivars, such as preservation of potential pollen viability, improvement of pollen germination, and increase in the rate of ovule fertilization. However, cultivars responded differently to mounting IBA doses. As IBA concentration rose, the number of pollen grains reduced in cultivar Caipira and increased in cultivar Wisconsin MR28, as well as the number of female flowers remained stable in cultivar Caipira and increased in cultivar Wisconsin MR28. In addition, the amount of male flowers grew in cultivar Caipira and fell down in cultivar Wisconsin MR28 for IBA concentrations up to $100 \mu \mathrm{mol}$. The application of exogenous IBA, in concentrations up to $500 \mu \mathrm{mol}$, improved fecundation and the biological conditions for seed development in both cucumber cultivars. Thus, the use of IBA can potentially boost fruit yield and quality in cucumber. Nevertheless, flower sex regulation in cucumber by means of IBA exogenous application is a genotype-dependent phenomenon, and deserves further studies.

\section{REFERENCES}

BRENDA K; SCHEERENS JC; BEMIS WP. 1979. Sex expression in Cucurbita foetidissima HBK. Cucurbit Genetics Cooperative Report University of Arizona 2: 31-36. 
BUENO D; CAVALCANTI LK. 2003. Estudo da viabilidade dos grãos-de-pólen de flores de melão (Cucumis melo L.). Pesquisa Agropecuária Brasileira 16: 176-184.

DAN H; IMASEKI H; WASTENEYS GO; KAZAMA H. 2003. Ethylene stimulates endoreduplication but inhibits cytokinesis in cucumber hypocotyl epidermis. Plant Physiology 133: 1726-1731.

FRIEDLANDER D; ATSMON D; GALUN E. 1977. The effect of grafting on sex expression in cucumber. Plant Cell Physiology 18: 13431350.

GODOY AR; CARDOSO AI. 2004. Pegamento de frutos em pepino caipira não partenocárpico sob cultivo protegido com aplicação de ácido naftaleno acético. Bragantia 63: 237-243.

GOMES PR; RASEIRA MC; BAUDET LL; PESKE ST. 2003. Armazenamento do grãode-pólen de cebola (Allium cepa L.). Revista Brasileira de Sementes 25: 14-17.

IBGE. Instituto Brasileiro de Geografia e Estatística. 2005, April 16. Indicadores para Santa Catarina. Disponível em http:// www.ibge.gov.br/
KATER MM; FRANKEN J; CARNEY KJ; COLOMBO L; ANGENENT GC. 2001. Sex determination in the monoecious species cucumber is confined to specific floral whorls. Plant Cell 13: 481-494.

KATER MM; COLOMBO L; FRANKEN J; BUSSCHER M; MASIERO S; CAMPAGNE, ML; ANGENENT, M.C. 1998. Agamous multiple homologs of cucumber and petunia differ in the ability to induce the destiny of reproductive organ. The Plant Cell 10: 171182.

MENDONZA JFB. 1982. A expressão do sexo em pepino (Cucumis sativus L.) In: MULLER JJV; CASALLI VWD (eds). Seminários de Olericultura 5: 53-73.

NIENHUIS J; LOWER RL. 1979. Interspecific grafting to promote flowering in Cucumis hardwickii. Cucurbit Genetics Cooperative Report 2: 11-12.

NIJS AP; VISSER DL. 1999. Silver compounds inducing male flowers in gynoecious cucumbers. Institute for Horticultural Plant Breeding 11: 134-146.
SILVA ACF; AGOSTINI I; MULLER JJV; VIZZOTO VJ. 1992. Efeito de densidades populacionais sobre a produtividade de pepino para conserva. Horticultura Brasileira 10: 2829.

SILVAAC; LEITE IC; BRAZ, LT. 2000. Avaliação da viabilidade do pólen como possível indicativo de tolerância a altas temperaturas em genótipos de tomateiro. Revista Brasileira de Fisiologia Vegetal 12: 156-165.

STANKOVIC L; PRODANOVIC S. 2002. Silver nitrate effects on sex expression in cucumber. Acta Horticulturae 579: 203-206.

TAIZ L; ZEIGER, E. 2002. Flowering regulation. Plant Physiology 24: 581-610.

TAKAHASHI H; JAFFE MJ. 2003. Further studies of auxin and ACC induced feminization in the cucumber plant using ethylene inhibitors. Trends in Plant Science 3: 415-416.

YIN T; QUINN JA. 1995. Tests of a mechanistic model of one hormone regulating both sexes in Cucumis sativus (Cucurbitaceae). American Journal of Botany 82: 1537-1546. 